\title{
Ocena związku zapalenia dziąseł i poziomu hemoglobiny glikowanej z aktywnością fizyczną osób dorosłych z cukrzycą typu 1
}

\author{
Assessment of the relationship between gingivitis and the level of glycosylated hemoglobin \\ with physical activity in adults with type 1 diabetes
}

\author{
${ }^{1}$ Katedra i Klinika Chirurgii Stomatologicznej i Periodontologii, \\ Uniwersytet Medyczny im. Karola Marcinkowskiego w Poznaniu \\ Department of Dental Surgery and Periodontology, Poznan University of Medical Sciences, Poland \\ ${ }^{2}$ Katedra i Klinika Chorób Wewnętrznych i Diabetologii, \\ Uniwersytet Medyczny im. Karola Marcinkowskiego w Poznaniu \\ Department of Internal Medicine and Diabetology, Poznan University of Medical Sciences, Poland
}

DOI: http://dx.doi.org/10.20883/df.2021.12

\begin{abstract}
STRESZCZENIE
Wstęp. Hemoglobina glikowana A1c (HbA1c) jest jednym ze standardowych wskaźników oceny wyrównania metabolicznego cukrzycy i odzwierciedla ryzyko powikłań. Do istotnych powikłań towarzyszących cukrzycy w obrębie jamy ustnej zalicza się stany zapalne dziąseł i przyzębia, które bezpośrednio wpływają na zwiększenie insulinooporności i zaburzają wyrównanie metaboliczne. Istotną rolę w cukrzycy typu 1 odgrywają również czynniki środowiskowe, takie jak styl życia, sposób żywienia i aktywność fizyczną. Aktywność fizyczna stanowi istotny element postępowania w cukrzycy, gdyż sprzyja normalizacji masy ciała. Systematyczne podejmowanie wysiłku fizycznego jest bardzo ważnym sposobem na poprawę ogólnego stanu zdrowia.

Cel. Porównanie związku zapalenia dziąseł i poziomu hemoglobiny glikowanej z aktywnością fizyczną osób dorosłych z cukrzycą typu 1.

Materiał i metody. Do badania włączono 50 osób (23 mężczyzn) z cukrzycą typu 1 z medianą wieku 25 lat. Mediana czasu trwania cukrzycy w badanej grupie wyniosła 11 lat. Dokonano oznaczenia HbA1c oraz przeprowadzono badanie stomatologiczne z oceną wskaźnika Gl. Przeprowadzono wywiad pod kątem aktywności fizycznej badanych pacjentów.

Wyniki. Porównując badane zmienne, wykazano wyższe wartości badanej hemoglobiny glikowanej i wskaźnika dziąsłowego u pacjentów niedeklarujących aktywności fizycznej. Nie stwierdzono związku pomiędzy czasem trwania cukrzycy, płcią badanych osób a ich aktywnością fizyczną. Nieaktywni fizycznie badani byli starsi w porównaniu z grupą deklarującą aktywność fizyczną.
\end{abstract}

Słowa kluczowe: cukrzyca typu 1, zapalenie dziąseł, hemoglobina glikowana, aktywność fizyczna, choroba cywilizacyjna.

\section{ABSTRACT}

Introduction. Glycated hemoglobin A1c (HbA1c) is one of the standard indicators for the assessment of metabolic control of diabetes and reflects the risk of complications. Significant complications accompanying diabetes in the oral cavity include gingivitis and periodontitis, which directly increase insulin resistance and disturb metabolic control. Environmental factors such as lifestyle, diet and exercise also play an important role in type 1 diabetes. Physical activity is an important element of diabetes management as it promotes the normalization of body weight. Regular exercise is a very important way to improve your overall health.

Aim. Comparison of the relationship between gingivitis and the level of glycosylated hemoglobin with physical activity in adults with type 1 diabetes.

Material and Methods. The study included 50 subjects ( 23 male) with type 1 diabetes mellitus with a median age of 25. The median duration of diabetes in the study group was 11 years. HbA1c was determined and a dental examination with Gl assessment was performed. The interview was conducted in terms of physical activity of the studied patients. Results. Comparing the studied variables, higher values of the tested glycosylated hemoglobin and the gingival index were shown in patients without physical activity. There was no relationship between the duration of diabetes mellitus, gender of the examined people and their physical activity. The physically inactive respondents were older than the group declaring physical activity.

Keywords: type 1 diabetes, gingivitis, glycosylated hemoglobin, physical activity, civilization disease. 


\section{Wstęp}

Cukrzyca jest ogólnoustrojową chorobą metaboliczną charakteryzującą się bezwzględnym lub względnym niedoborem insuliny. W czasie trwania choroby cukrzycowej procesy gojenia są upośledzone. Dzieje się tak na skutek zaburzenia funkcji monocytów i makrofagów, utrzymującego się podwyższonego poziomu cytokin prozapalnych, zmniejszonej ekspresji czynników wzrostu prowadzącej do hamowania proliferacji komórkowej i syntezy macierzy zewnątrzkomórkowej [1]. Innym sugerowanym mechanizmem jest zwiększenie apoptozy fibroblastów z równoczesnym odkładaniem końcowych produktów glikacji białek AGE [2]. Hemoglobina glikowana A1c (HbA1c) jest standardowym wskaźnikiem ocenianym przy kontroli wyrównania cukrzycy. Odzwierciedla średnią glikemię w poprzedzającym okresie około trzech miesięcy, przy czym około $50 \%$ obecnej we krwi HbA1c powstaje w ciągu ostatniego miesiąca przed wykonaniem oznaczenia [3]. Wykazano silną wartość predykcyjną HbA1c dla przewlekłych powikłań cukrzycy [4], w tym mikro i makroangiopatii w tkankach [5]. Zapalenie dziąseł i przyzębia u chorych na cukrzycę jest jednym z obserwowanych klinicznie powikłań. Potwierdzają to podwyższone wskaźniki krwawienia ze szczeliny dziąsłowej, głębokości kieszonek i utraty przyczepu łącznotkankowego [6]. Równocześnie wiele mediatorów zapalnych, powstających miejscowo w tkankach przyzębia czy wydzielanych do krwiobiegu, takich jak interleukina $\beta$ (IL- $\beta$ ) i TNF- a wpływa na przebieg cukrzycy. TNF-a oraz IL-1 $\beta$ zwiększają fosforylację seryn w białkach receptora insulinowego (IRS), znajdującego się na powierzchni komórek docelowych dla insuliny. Konsekwencją tego procesu jest zaburzenie przekazywania sygnału i zmniejszone oddziaływanie insuliny na komórki [7]. Wykazują one wówczas mniejszą wrażliwość na insulinę, zmniejsza się pobieranie glukozy z krwi oraz magazynowanie glukozy w tkankach. Prowadzi to do zaburzenia gospodarki cukrowej organizmu i hiperglikemii, z niekorzystnymi skutkami także dla tkanek przyzębia [8]. U pacjentów chorujących na cukrzycę leczenie współwystępującej choroby przyzębia może znacznie poprawić kon- trolę wyrównania cukrzycy. Dane na temat związku pomiędzy cukrzycą a zapaleniem dziąseł i przyzębia są nadal niezadowalające. Wiadomo jednak, że pomiędzy tymi dwiema jednostkami chorobowymi istnieje ścisła, dwukierunkowa zależność. Zarówno niewyrównana cukrzyca, jak i przewlekły stan zapalny w tkankach przyzębia, mają na siebie wzajemny, komplikujący przebieg wpływ $[9,10]$.

Aktywność fizyczna wpływa zarówno na poprawę zdrowia ogólnego, jakości życia oraz przebieg cukrzycy. Usprawnia metabolizm glukozy, bierze udział w redukcji tkanki tłuszczowej, obniża ciśnienie tętnicze, zmniejsza stężenie hemoglobiny glikowanej, zmniejsza masę ciała oraz obwód talii [11]. Głównym celem leczenia cukrzycy jest zwiększenie wrażliwości tkanek na insulinę. Wysiłek fizyczny może korzystnie wiązać się z homeostazą glukozy. Na zmniejszenie insulinooporności prawdopodobnie wpływa redukcja tkanki tłuszczowej wewnątrz jamy brzusznej [12]. Udowodniono, że niezależnie od zmniejszenia masy ciała, wysiłek fizyczny zwiększa wrażliwość tkanek na insulinę. Dzieje się to głównie wskutek zwiększenia aktywności glukotransporterów 4 (GLUT4) w komórkach mięśni szkieletowych w czasie pojedynczego wysiłku fizycznego oraz zwiększenia ich syntezy będącego skutkiem regularnych treningów. Również wzrost zapotrzebowania organizmu na tlen podczas wysiłku fizycznego prowadzi do zwiększenia stopnia zużycia zapasów glikogenu i trójglicerydów w mięśniach szkieletowych oraz wolnych kwasów tłuszczowych i glukozy pochodzących z wątroby [13].

\section{Cel}

Celem badania było porównanie związku zapalenia dziąseł i poziomu hemoglobiny glikowanej, z aktywnością fizyczną osób dorosłych z cukrzycą typu 1.

\section{Materiał i metody}

Po uzyskaniu zgody Komisji Bioetycznej do badania włączono 50 osób dorosłych (23 mężczyzn) z cukrzycą typu $1 \mathrm{w}$ wieku 18-45 lat (średnia wieku 27,1) oraz z medianą trwania cukrzycy 11 (Tabela 1).

Tabela 1. Charakterystyka badanej grupy $(\mathrm{N}=50)$

Table 1. Characteristics of the studied group $(N=50)$

\begin{tabular}{|l|c|c|c|c|c|c|}
\hline \multicolumn{1}{|c|}{ Parametr } & Minimum & Maksimum & Średnia & Mediana & SD & IQR \\
\hline Wiek [lata] & 18 & 45 & 27,14 & 25 & 7,7 & $21-32$ \\
\hline Czas trwania cukrzycy [lata] & 4 & 14 & 10,62 & 11 & 2,8 & $9-13$ \\
\hline HbA1c [\%] & 5,8 & 14,4 & 8,21 & 7,7 & 1,7 & $7,1-8,6$ \\
\hline Gl & 0,00 & 1,25 & 0,76 & 0,83 & 0,3 & $0,5-1,0$ \\
\hline Płeć [k/m] & \multicolumn{7}{|c|}{$27 / 23$} \\
\hline
\end{tabular}


Wszyscy badani wyrazili świadomą zgodę na udział w badaniu. Kryteria wykluczające stanowiły: aktualne leczenie ortodontyczne, ciąża. U wszystkich pacjentów przeprowadzono kliniczne badanie stanu dziąseł z pomocą wskaźnika dziąsłowego (Gl). Oceny dokonywał jeden lekarz celem obiektywizacji wyników. Wskaźnik Gl oceniano przy zębach $16,11,24,36,31,44$, a w przypadku niewyrznięcia lub braku zębów 24 i/lub 44 oceniano stan dziąseł przy zębach 26 i/lub 46 . Oceny dokonywano w odniesieniu do czterostopniowej skali stanu dziąsła: 0 - zdrowe dziąsło, kolor bladoróżowy; 1 - łagodne zapalenie, lekka zmiana w zabarwieniu dziąsła i łagodne zmiany struktury tkanki, brak krwawienia przy zgłębnikowaniu; 2 - umiarkowane zapalenie: zaczerwienienie, obrzęk, połysk i przerost dziąsła, krwawienie przy ucisku lub zgłębnikowaniu; 3 - ciężkie zapalenie: znaczne zaczerwienienie i obrzęk dziąsła, owrzodzenie, skłonność do samoistnego krwawienia. Wartość mediany wskaźnika Gl przyjęto za podstawę podziału grupy na osoby z lub bez zapalenia dziąseł. U wszystkich pacjentów oznaczono na czczo odsetek hemoglobiny glikowanej (HbA1c) z wykorzystaniem standardowych metod laboratoryjnych. $U$ badanych pacjentów przeprowadzono szczegółowy wywiad dotyczący aktywności fizycznej. Celem sklasyfikowania pacjentów wykazujących aktywność fizyczną przyjęto deklarację podejmowania przez nich aktywności ruchowych wilości $>30$ minut codziennie przez 7 dni w tygodniu. Za aktywność fizyczną przyjęto bieganie, jazdę na rowerze, jazdę na rolkach, pływanie, fitness, gry zespołowe oraz spacery.

Wyniki poddano analizie statystycznej za pomocą programu Statistica P wersja 10.0. Za istotny statystycznie przyjęto poziom istotności $p<0,05$. Ocenę zgodności rozkładu zmiennych z rozkładem normalnym wykonano za pomocą testu Kołmogorowa-Smirnowa z poprawką Lillieforsa. Do analizy danych użyto testów nieparametrycznych. W analizie statystycznej wykorzystano test U Manna-Whitneya oraz chi-kwadrat. Wyniki przedstawiono jako liczebności oraz średnie, odchylenia standardowe i rozstępy międzykwartylowe (IQR).

\section{Wyniki}

Średni poziom hemoglobiny glikowanej HbA1c wynosił 8,21 [\%], natomiast średnia wartość wskaźnika dziąsłowego Gl wyniosła 0,76 (Tabela 1). Badaną grupę podzielono ze względu na deklarowaną aktywność fizyczną oraz brak deklarowanej aktywności fizycznej. Pacjenci deklarujący aktywność ruchową charakteryzowali się młodszym wiekiem, $22,5(19-25,5)$ lat vs $30(24-34)$ lat; $p=0,008$, niższym poziomem hemoglobiny glikowanej HbA1c, $7,5 \%(6,75-8,45 \%)$ vs $8,1 \%(7,5-9,2 \%) ; p=0,03$ oraz niższymi wartościami wskaźnika dziąsłowego $\mathrm{Gl}$, $0,54(0,29-0,87)$ vs $0,98(0,83-1,08) ; p=0,0002$. Grupy aktywnych i nieaktywnych fizycznie nie różniły się w zakresie płci oraz czasu trwania cukrzycy (Tabela 2). W całej grupie badanie wykazało dodatnią korelację między wskaźnikiem dziąsłowym

Tabela 2. Porównanie grup w zależności od deklarowanej aktywności fizycznej. Test U Manna-Whitneya. Mediana (IQR) lub n (\%). *test chi-kwadrat

Table 2. Comparison of groups depending on the declared physical activity. The MannWhitney U Test. Median (IQR) or n (\%). * chi-square test

\begin{tabular}{|l|c|c|c|}
\hline \multicolumn{1}{|c|}{ Parametr } & Aktywni fizycznie & Nieaktywni fizycznie & p \\
\hline Wiek [lata] & $22,5(19-25,5)$ & $30(24-34)$ & 0,008 \\
\hline Płać, mężczyźni, n(\%) & $12(50 \%)$ & $11(42 \%)$ & $0,6^{*}$ \\
\hline Czas trwania cukrzycy [lata] & $11(9-13)$ & $11(9-13)$ & 0,7 \\
\hline HbA1c [\%] & $7,5(6,75-8,45)$ & $8,1(7,5-9,2)$ & 0,03 \\
\hline Gl & $0,54(0,29-0,87)$ & $0,98(0,83-1,08)$ & 0,0002 \\
\hline
\end{tabular}

Tabela 3. Korelacja między indeksem dziąsłowym a poziomem HbA1c w badanej grupie. Współczynnik korelacji rang Spearmana, $\mathrm{R}$

Table 3. Correlation between the gingival index and the level of HbA1c in the study group. Spearman's rank correlation coefficient, $R$

\begin{tabular}{|l|c|}
\hline Skorelowane zmienne & Dorośli \\
\hline $\mathrm{HbA} 1 \mathrm{c} \& \mathrm{Gl}$ & $\mathrm{Rs}=0,49 ; \mathrm{p}=0,0002$ \\
\hline
\end{tabular}

* $p<0,05$ poziom istotności statystycznie istotny 
a poziomem hemoglobiny glikowanej ( $\mathrm{Rs}=0,49$; $p=0,0002$ ) (Tabela 3).

\section{Dyskusja}

Wyniki badań związanych z wyrównaniem metabolicznym w cukrzycy w odniesieniu do chorób dziąseł i przyzębia są niekiedy trudne do porównania. Niejednoznaczność interpretacji związana jest często z niewielką liczebnością badanych grup oraz zastosowaniem różnych wskaźników pozwalających na ocenę stanu jamy ustnej [14]. W prezentowanym badaniu w grupie 50 osób z cukrzycą typu 1 ocenie poddano stan dziąseł przy pomocy wskaźnika dziąsłowego (GI).Wyboru wskaźnika dokonano ze względu na łatwość stosowania badania w warunkach ambulatoryjnych oraz fakt braku wspótistniejących objawów destrukcji tkanek przyzębia w badanej grupie. Niemalże $100 \%$ badanych miało natomiast zapalenie dziąseł. Aktualne badania pokazują, że leczenie obecnych w jamie ustnej stanów zapalnych dziąseł i przyzębia może poprawić wartości hemoglobiny glikowanej [15], na poziomie $0,4 \%$ [16]. W zapaleniu przyzębia przewlekła infekcja tkanek jamy ustnej zwiększą insulinoopornośc, przyczyniając się do pogorszenia wyrównania metabolicznego cukrzycy $[17,18]$. Reakcja bakteryjnych produktów ubocznych z fagocytami i fibroblastami indukuje chroniczny wyrzut cytokin prozapalnych, m.in. interleukin: IL-1ß, IL-6, czynnik martwicy guza (TNF-a), prostaglandyny E2 (PGE2) oraz białka ostrej fazy C-reaktywnego (CRP) [19]. W przeprowadzonym badaniu zaobserwowano istotną statystycznie korelację pomiędzy poziomem HbA1c a wskaźnikiem dziąsłowym. Zapalenie dziąseł u pacjentów z cukrzycą typu 1 może być zależne od wieku i ma ścisły związek z wyrównaniem metabolicznym (odzwierciedlanym przez poziom hemoglobiny glikowanej) [20]. Pacjenci ze współistniejącą cukrzycą oraz chorobą dziąseł i przyzębia, niezależnie od wieku, powinni zostać poinformowani i odpowiednio wyedukowani o interakcji pomiędzy higieną jamy ustnej, stanem przyzębia i ich zdrowiem ogólnym oraz korzystnym wpływie aktywności fizycznej [21]. Leczenie zapaleń dziąseł i przyzębia powinno przebiegać w trzech fazach: higienizacyjnej, korekcyjnej oraz podtrzymującej. Obie pierwsze fazy nazywane są leczeniem aktywnym, a faza trzecia podtrzymuje uzyskane już wyniki leczenia [22]. W leczeniu cukrzycy konieczna jest współpraca zespołu - diabetologa oraz stomatologa, ponieważ istnieje dwukierunkowa zależność pomiędzy cukrzycą i chorobą przyzębia [23]. Pacjenci z nierozpoznaną cukrzycą zgłaszający stomatologowi objawy sugerujące możliwość jej występowania, powinni być kierowani do odpowiedniego lekarza, który powinien zlecić wykonanie podstawowych badań, w celu ustalenia rozpoznania i podjęcia właściwego leczenia [24]. Wczesne rozpoznanie cukrzycy i dobra kontrola glikemii korzystnie wpływają na przebieg choroby podstawowej, jak i na przebieg choroby przyzębia [25]. Leczenie choroby przyzębia może zmniejszyć częstość powikłań cukrzycy, dlatego też, jeżeli pacjent nie jest objęty opieką stomatologiczną, lekarz prowadzący powinien skierować chorego na cukrzycę do stomatologa celem diagnostyki, profilaktyki oraz leczenia ewentualnej choroby przyzębia [26]. Deklarowana przez badanych aktywność fizyczna korzystnie wpływała na badane parametry - niższy poziom hemoglobiny glijowanej oraz niższe wartości wskaźnika dziąsłowego w porównaniu do pacjentów niedeklarujących aktywności ruchowej. Wszystkie rodzaje aktywności fizycznej mogą być uprawiane przez chorych na cukrzycę typu 1, u których nie występują powikłania, a cukrzyca jest dobrze wyrównana [27]. Zdolność do samodzielnej modyfikacji dawek insuliny oraz diety, która umożliwia bezpieczny udział w zajęciach związanych z wysiłkiem fizycznym i zwiększą wydolność, uważa się obecnie za istotny element postępowania terapeutycznego u tych pacjentów [28, 29]. Szczególnie istotne jest zapisywanie przez chorego danych dotyczących glikemii mierzonej po wysiłku fizycznym, a następnie korzystanie z nich w celu uzyskania poprawy wydolności wysiłkowej i zachowania bezpieczeństwa. Należy zachęcać do ćwiczeń osoby z cukrzycą typu 1 $z$ tego samego powodu, dla którego należy zachęcać do tego wszystkich ludzi. Regularne ćwiczenia fizyczne mogą zmniejszyć czynniki ryzyka chorób układu krążenia i uważa się, że poprawiają one ogólną jakość życia [30, 31].

\section{Oświadczenia}

Oświadczenie dotyczące konfliktu interesów Autorzy deklarują brak konfliktu interesów w autorstwie oraz publikacji pracy.

Źródła finansowania

Autorzy deklarują brak źródeł finansowania.

\section{Piśmiennictwo}

[1] Aldridge JP, Lester V, Watts TL, Collins A, Viberti $\mathrm{G}$, Wilson RF. Single-blind studies of the effects of improved periodontal health on metabolic control in type 1 diabetes mellitus. J Clin Periodontol. 1995;22:271-275.

[2] Al-Shammari KF, Al-Ansari JM, Moussa NM, Al-Arouj $\mathrm{M}$, Wang HL. Association of periodontal disease severity with diabetes duration and diabetic compli- 
cations in patients with type 1 diabetes mellitus. J Int Acad Periodontol. 2006;8(4):109-114.

[3] Ship JA. Diabetes and oral health: an overview. J Am Dent Assoc. 2003;134:4S-10S.

[4] Bissett SM, Stone KM, Rapley T, Preshaw PM. An exploratory qualitative interview study about collaboration between medicine and dentistry in relation to diabetes management. BMJ Open. 2013;3:e002192.

[5] Chavarry NG, Vettore MV, Sansone C, Sheiham A. The relationship between diabetes mellitus and destructive periodontal disease: a meta-analysis. Oral Health Prev Dent. 2009;7:107-127.

[6] Al-Zahrani MS, Bissada NF, Borawskit EA. Obesity and periodontal disease in young, middle-aged, and older adults. J Periodontol. 2003;74:610-615.

[7] D'Aiuto F, Parkar M, Andreou G, Suvan J, Brett PM, Ready D, Tonetti MS. Periodontitis and systemic inflammation: control of the local infection is associated with a reduction in serum inflammatory markers. J Dent Res. 2004;83(2):156-60.

[8] Cianciola LJ, Park PH, Bruck E, Mosovich L, Genco RJ. Prevalence of periodontal disease in insulin-dependent mellitus (juvenile diabetes). J Am Dent Assoc. 1982;104: 653-660.

[9] Duda-Sobczak A, Lipski J, Tarnowski M, Surdacka A, Zozulinska-ZiolkiewiczD, Wyganowska-Swiatkowska M. Association of skin autofluorescence - a marker of advanced glycation end products accumulation with periodontal inflammation in adults with type 1 diabetes. Pol Arch Inter Med. 2017;127:708-718.

[10] Ervasti T, Knuuttila M, Pohjamo L, Haukipuro K. Relation between control of diabetes and gingival bleeding. J Periodontol. 1985;56(3):154-157.

[11] Zielinska K, Bysiak-Korus D, Sosona-Kondera A, Banaś E, Bosowska J, Strojek K. Ocena częstości występowania hipoglikemii w zależności od aktywności fizycznej. Diabetologia Praktyczna. 2018;4(2):115-120.

[12] Mędrela-Kuder E, Bis H. Porównanie aktywności fizycznej i diety u kobiet i mężczyzn chorych na cukrzycę typu 2. Med Og Nauk Zdr. 2014;20(1):31-33.

[13] Dietrich T, Ower P, Tank M et al. Periodontal diagnosis in the context of the 2017 classification system of periodontal diseases and conditions - implementation in clinical practice. Br Dent J. 2019;226:16-22.

[14] Llambés F, Silvestre FJ, Hernández-Mijares A, Guiha $\mathrm{R}$, Caffesse R. The effect of periodontal treatment on metabolic control of type 1 diabetes mellitus. Clin Oral Investig. 2008;12:337-343.

[15] Loos BG. Systemic markers of inflammation in periodontitis. J Periodontol. 2005;76:2106-2115.

[16] Lorenzo C, Haffner SM. Performance characteristics of the new definition of diabetes: the insulin resistance atherosclerosis study. Diabetes Care. 2010;33:335-7.

[17] Mealey BL, Ocampo GL. Diabetes mellitus and periodontal disease. Periodontol 2000. 2007;44:127-153.

[18] Orbak R, Simsek S, Orbak Z, Kavrut F, Colak M. The influence of type-1 diabetes mellitus on dentition and oral health in children and adolescents. Yons Med J. 2008; 49:357-365.
[19] Naguib G, Al-Mushat H, Desta T, Graves D. Diabetes prolongs the inflammatory response to a bacterial stimulus throught cytokine dysregulation. J Ivestig Dermatol. 2004;123:87-92.

[20] O'Dowd LK, Durham J, McCracken Gl, Preshaw PM. Patients' experiences of the impact of periodontal disease. J Clin Periodontol. 2010;37:334-339.

[21] Lipski J, Duda-Sobczak A, Napierala M, Florek E, Zozulinska-Ziolkiewicz D, Wyganowska-Swiatkowska M. Influence of Chlorhexidine and Cetylpyridine on Periodontal Status and Indicators of Oxidative Stress in Patients with Type 1 Diabetes. Antioxidants. 2021;10:1732.

[22] Pihlstrom BL, Michalowicz BS, Johnson NW. Periodontal diseases. Lancet. 2005;366:1809-1820.

[23] Pischon N, Heng N, Bernimoulin JP, Kleber BM, Willich SN, Pischon T. Obesity, inflammation, and periodontal disease. J Dent Res. 2007;86:400-409.

[24] Lalla E, Cheng B, Lal S, Kaplan S, Softness B, Greenberg E, Goland RS, Lamster IB. Diabetes-related parameters and periodontal conditions in children. J Periodontal Res. 2007;42:345-349.

[25] Preshaw PM, Alba AL, Herrera D et al. Periodontitis and diabetes: a two-way relationship. Diabetologia. 2012;55:21-31.

[26] Tarnowski M, Duda-Sobczak A, Zozulińska-Ziółkiewicz D, Wyganowska-Świątkowska M. Insulinoterapia przy użyciu osobistej pompy insulinowej oraz lepsze wyrównanie glikemii są związane z mniejszą akumulacją płytki nazębnej u dorosłych chorych na cukrzycę typu 1. Dental Forum. 2018;2(XLVI):11-16.

[27] Lamster IB, Lalla E, Borgnakke WS, Taylor GW. The relationship between oral health and diabetes mellitus. J Am Dent Assoc. 2008;139(Suppl.):19S-24S.

[28] Sanz M, Ceriello A, Buysschaert M et al. Scientific evidence on the links between periodontal diseases and diabetes: Consensus report and guidelines of the joint workshop on periodontal diseases and diabetes by the International Diabetes Federation and the European Federation of Periodontology. Diabetes Res Clin Pract. 2018;137:231-241.

[29] Xavier AC, Silva IN, Costa FD, Correa DS Periodontal status in children and adolescents with type 1 diabetes mellitus, Arqu Brasil Endocrin Metabol. 2009; 53:348-354.

[30] World Health Organization (WHO). Use of glycated haemoglobin (HbA1c) in the diagnosis of diabetes mellitus, 2011.

[31] World Health Organization (WHO). Definition and diagnosis of diabetes mellitus and intermediate hyperglycaemia, 2006.

Zaakceptowano do edycji: 2022-01-24 Zaakceptowano do publikacji: 2022-01-24

Adres do korespondencji: Jakub Lipski, e-mail: jakublipski@ump.edu.pl 